\title{
Circulating IgG Antibody to Protamine in Patients Treated with Protamine-Insulins
}

\author{
A. B. Kurtz ${ }^{1}$, R.S. Gray ${ }^{2}$, S. Markanday ${ }^{1}$, and J.D. N. Nabarro ${ }^{1}$ \\ 'The Cobbold Laboratories, The Middlesex Hospital, London and ${ }^{2}$ The Royal Infirmary Edinburgh, UK
}

Summary. Sera from patients treated with different types of protamine-insulin were assayed for $\mathrm{IgG}$ antibody to protamine. A high prevalence of circulating antibody was found in patients treated with either bovine isophane insulin ( 26 out of 28 patients; 26 of whom also had antibodies to insulin), or bovine protamine zinc insulin ( 27 out of 30 patients; all 30 had antibodies to insulin). In sera from 24 patients treated with highly purified porcine isophane insulin, protamine antibody was detected in nine; circulating insulin-antibody was de- tected in 12 patients, eight of whom had protamine-antibody; in the 12 patients with no detectable antibody to insulin, antibody to protamine was detected in only one $\left(\chi^{2}=8.7, p<0.01\right)$. This relationship between insulin and protamine antigenicity is of interest as it suggests that the protamine-insulin complex is itself immunogenic.

Key words: Isophane insulin, protamine zinc insulin, insulin-antibody, protamine, protamine-antibody.
Protamine has been used as a retardant of insulin absorption since the nineteen-thirties [1]. It is a basic polypeptide found in sperm and because of its charge it will bind acidic proteins; the usual source of the protamine used in insulin manufacture has been salmon or rainbow trout. Severel different protamines can be found even in one species; a typical structure is the salmonprotamine salmine A1 with molecular weight of 4,000 daltons and containing 32 amino acids, of which 21 are arginine [2]. At neutral $\mathrm{pH}$ insulin and protamine form an insoluble ionically bonded complex which crystalizes, under suitable conditions, in the presence of zinc into needle-shaped crystals [3]. This preparation was initially called protamine-insulinate to indicate its salt-like nature [1]. In isophane insulins the usual molar ratio of protamine to insulin is about $1: 6$ (i.e. $0.3-0.4 \mathrm{mg}$ protamine $/ 100 \mathrm{U}$ insulin) with more protamine being used in protamine zinc preparations $(1-1.7 \mathrm{mg} / 100 \mathrm{U}$ insulin). The protamine in protamineinsulin has been found to be immunogenic; in one report antibodies were detected by complement fixation [4], and in another by lymphocyte proliferation [5]. In this study we have looked for circulating IgG antibody to protamine in patients receiving different types of protamine-insulin.

\section{Methods}

\section{Patient Groups}

Serum was collected from patients who had been treated only with either conventional bovine isophane and soluble insulins $(n=28$, age range 15-66 years) or with bovine protamine zinc and soluble insulins ( $n=30$, age range: $28-75$ years). Serum was collected also from 24 patients treated only with highly purified porcine isophane and soluble insulins for one year $(n=24$, age range $16-55$ years, median 27 years and daily insulin dose $24-60 \mathrm{U}$, median $36 \mathrm{U}$ ).

No patient had a history of skin allergy or of resistance to insulin.

\section{Assay Methods}

Antibodies to both protamine and insulin were determined by measurement of the binding of the labelled antigen by serum and the result expressed as a percentage of the total labelled antigen.

Protamine (from salmon; obtained from Weddel Pharmaceuticals, Stockport, UK) was labelled with ${ }^{125}$ iodine using the technique described by Bolton and Hunter [6]. Protamine $(5 \mu \mathrm{g})$ was conjugated with $1 \mathrm{mCi}$ of the $\mathrm{N}$-succinimidyl ester of 3-(4-hydroxy, $5-\left({ }^{125} \mathrm{I}\right)$ iodophenyl propionate (sp. act. $2000 \mathrm{Ci} / \mathrm{mmol}$; Amersham International, Amersham, Bucks, UK). Separation of the products of iodination was performed on a Sephadex G50 F column $(15 \times 0.4 \mathrm{~cm})$ in sodium phosphate buffer $(0.05 \mathrm{~mol} / 1, \mathrm{pH} 7.5)$, containing gelatin $(2.5 \mathrm{~g} / \mathrm{l})$. The first peak of labelled material contained the antigen. Analysis showed that $92 \%$ of the label was precipitated by trichloracetic acid $(10 \% \mathrm{v} / \mathrm{v})$. Initial batches of labelled protamine were pre- 
Table 1. The binding of labelled protamine and insulin by serum of patients treated with bovine protamine zinc insulin or bovine isophane insulin

\begin{tabular}{lllllll}
\hline Insulin & $\begin{array}{l}\text { No of } \\
\text { subjects }\end{array}$ & $\begin{array}{l}\text { Age } \\
\text { (years) }\end{array}$ & $\begin{array}{l}\text { Duration } \\
\text { (years) }\end{array}$ & $\begin{array}{l}\text { Dose } \\
(\mathrm{U})\end{array}$ & $\begin{array}{l}\text { Protamine B } \\
(\%)\end{array}$ & $\begin{array}{l}\text { Insulin B } \\
(\%)\end{array}$ \\
\hline Protamine zinc insulin & 30 & $50.1 \pm 11.7^{\text {a }}$ & $20.7 \pm 10$ & $57.3 \pm 28$ & $20.8 \pm 10.1$ & $27.8 \pm 16.8^{\text {a }}$ \\
Isophane insulin & 28 & $38.7 \pm 16.1$ & $18.8 \pm 7.7$ & $48.5 \pm 16.1$ & $18.1 \pm 6.1$ & $12.6 \pm 10.2$ \\
\hline
\end{tabular}

Results are expressed as mean $\pm \mathrm{SD}$

${ }^{2}$ Significant differences between the two groups of patients at $p<0.01$

pared in our laboratory; subsequent batches, similarily prepared, were supplied by Nordisk, Gentofte, Denmark.

Serum $(10 \mu \mathrm{l})$ was incubated for $16 \mathrm{~h}$ at $4^{\circ} \mathrm{C}$ with labelled protamine (approximately $20,000 \mathrm{cpm})$ in buffer $(200 \mu 1)$, containing sodium phosphate $(0.05 \mathrm{~mol} / \mathrm{l}), \mathrm{pH} 7.5$, sodium chloride $(9 \mathrm{~g} / \mathrm{l})$ and $\mathrm{ED}$ TA $(0.01 \mathrm{~mol} / \mathrm{l})$. Rabbit anti-human IgG $(100 \mu \mathrm{l} / \mathrm{tube}$; A090 from Dakopatts, Copenhagen, Denmark) was then added and the incubation continued for $20-24 \mathrm{~h}$ at $4{ }^{\circ} \mathrm{C}$. Phosphate buffered saline $(1.5 \mathrm{ml} /$ tube) containing cetyl trimethyl ammonium bromide $(10 \mathrm{~g} / 1)$ was then added and the tubes vortexed and then centrifuged at $2,500 \mathrm{rev} / \mathrm{min}$ for $30 \mathrm{~min}$. The precipitates, containing the antibody-bound labelled protamine, were washed with $1.5 \mathrm{ml}$ of buffer containing Triton X100 $(0.5 \mathrm{~g} / \mathrm{l})$, centrifuged and finally washed with $1.5 \mathrm{ml}$ of the the buffer containing cetyl trimethyl ammonium bromide before counting. Nonspecific binding, which was determined by including sera from subjects who had never received insulin averaged $4.9 \pm 0.7 \%$ (mean \pm SD). Displacement curves were produced by the addition of unlabelled protamine at concentrations $₹ 20 \mathrm{ng} /$ tube.

The method of determining insulin binding has been described [7]: a serum sample $(20 \mu \mathrm{l})$ was used with a polyethylene glycol separation procedure. The labelled bovine insulin used (Novo Laboratories, Copenhagen, Denmark) had a specific activity of $25 \mu \mathrm{Ci} / \mu \mathrm{g}$. Porcine insulin labelled at the A14 position (spec. act. $250 \mu \mathrm{Ci} / \mu \mathrm{g}$ ) was prepared using the method described by Linde and Hansen [8]. Nonspecific binding averaged $1.4 \pm 0.2 \%$ (mean \pm SD).

Antibody to insulin or protamine was considered to have been detected if the binding of labelled antigen exceeded the non-specific binding plus three standard deviations. Statistical analyses were with the chi-square test, Student's t-test and least squares regression.

\section{Results}

The binding of labelled insulin and protamine in the groups of patients treated with bovine isophane and protamine zinc insulins are shown in Table 1 together, with details of age, duration of diabetes and daily insulin dose. The group treated with protamine zinc insulin was significantly older and the insulin binding significantly higher. There was no difference in the prevalence or levels of protamine antibody. Of the 28 patients treated with bovine isophane and soluble insulins, antibody to protamine was detected in 26 and of the 30 patients treated with protamine zinc and soluble insulins antibody was detected in 27 patients. Insulin antibody was detected in 26 out of 28 treated with bovine isophane insulin and, of note, the two subjects in whom insulinantibody was not detected did have protamine-antibody. All patients treated with protamine zinc insulin had antibody to insulin. In neither group was there any correlation between the levels of insulin binding and protamine binding (in both groups $r=0.10$, NS); there was also no correlation of either age or duration of treatment with the levels of binding.
The prevalence of both insulin and protamine antibodies was much lower in the 24 patients treated for only one year with highly purified porcine soluble and isophane insulins. The binding of insulin by serum ranged from 1.2 to $47 \%$ (mean $\pm \mathrm{SD} ; 12.1 \pm 12.3 \%$ ) with antibody detected in 12 , while protamine binding ranged from 40 to $43 \%$ (mean $\pm \mathrm{SD}, 15.2 \pm 12 \%$ ) with antibody detected in nine. Sera from eight of the 12 subjects which bound insulin also bound protamine while the serum from only one subject did not bind insulin but did bind protamine $\left(\chi^{2}=8.7, p<0.01\right)$.

Two sera with high protamine-binding were studied in displacement assays. In both, labelled protamine was displaced by unlabelled protamine; $50 \%$ displacement occurred at concentrations of protamine of 25 and $40 \mathrm{ng} / \mathrm{ml}$. The inclusion of protamine $(5 \mu \mathrm{g} / \mathrm{ml}) \mathrm{com}-$ pletely blocked specific binding although insulin $(125 \mathrm{U} / 1)$ did not displace the labelled protamine.

\section{Discussion}

This study shows a high prevalence of circulating antibodies to protamine and to insulin in patients on longterm treatment with bovine protamine zinc and bovine isophane insulins. These two groups of patients were not strictly comparable, the group treated with protamine zinc insulin being somewhat older; nevertheless, there was no significant difference in the prevalence or levels of antibodies to protamine. However, in the group treated for a short time with highly purified porcine isophane insulin, the prevalence of antibodies to protamine and to insulin was much lower. The latter group was not comparable to the other groups of patients; however, the dissociation of protamine and insulin immunogenicity is of interest in this group.

In comparison to insulin, little attention has been paid to the immunogenicity of protamine. It has been commented that skin allergy problems are more common with protamine-insulin $[8,9]$ than with other insulin preparations, and in a case report in which acute urticaria followed injection of NPH insulin, skin tests indicated allergy to protamine and not to insulin and desensitization with protamine was achieved [10]. In an investigation of protamine-antibody formation following vasectomy, one 'control' subject's serum was found by a complement fixation test, to be positive; this patient had been treated with protamine-insulin [4]. Ros- 
enthal found that some protamine-insulin treated patients had responded immunologically to protamine as judged by the lymphocyte proliferation test [5].

The determination of protamine binding to antibodies in serum presented several methodological problems. The preparation of the labelled material gave rise to difficulties. Protamine is heterogeneous and does not contain tyrosine. Iodination was achieved by conjugation with the Bolton Hunter reagent. The products of this reaction included immunoreactive labelled protamine in relatively low yield (20\%) together with lower molecular weight material that was not precipitated by trichloracetic acid and was not immunoreactive. Because of its basic nature protamine associates with acidic proteins. The problem of separation of antibodybound and unbound labelled protamine, in the presence of binding of labelled protamine to other proteins, was overcome by using a double antibody technique, which ensures that only IgG-bound label is precipitated when a cationic detergent included to block the nonspecific binding of protamine to acidic proteins. When the non-specific polyethylene glycol separation method, as used for insulin, was tried with labelled protamine, $70 \%$ or more of the label was precipitated in control sera.

The antigenic determinants for porcine insulin could occur in physically or chemically altered insulin or in complexes such as those formed by protamine and insulin [11]. In animal studies the immune response genes have been closely associated with the immunological response to insulins of differing amino acid sequences [12]. In man the situation is less clear, possibly because most patients have been 'immunized' with multiple and varying insulin preparations. However, it does appear that HLA-B7 subjects produce less antibody whereas B15 subjects produce more [13]. Although much attention has been focussed on antibodies to insulin and hormonal contaminants, the implications of antibodies to protamine have been overlooked. The present finding that insulin and protamine immunogenicities are linked could indicate that a protamine- insulin complex forms a common antigen or that the individual antigens are genetically associated.
Acknowledgements. We are grateful to Dr. A.-M. Kappelgaard (Nordisk Insulinlaboratorium, Gentofte, Denmark) for gifts of labelled protamine, and to Nordisk-UK and the Special Trustees of The Middlesex Hospital for support.

\section{References}

1. Hagedorn HC, Jensen BN, Krarup NB, Wodstrup I (1936) Protamine insulinate. JAMA 106: 177-180

2. Delange RJ, Smith EK (1979) Chromosomal proteins. In: Neurath H, Hill RL (eds) The proteins, 3rd edn. Academic Press, New York, pp 119-243

3. Scott DA, Fisher AM (1936) Studies on insulin with protamine. J Pharm Exp Therap 58: 78 -92

4. Samuel T, Kolk AHJ, Rumke P (1978) Studies on the immunogenicity of protamines in humans and experimental animals by means of a micro-complement fixation test. Clin Exp Immunol 33: 252-260

5. Rosenthal AS (1980) Regulation of the immune response - role of the macrophage. New Engl J Med 20: 1153-1156

6. Bolton AE, Hunter WM (1973) The labelling of proteins to high specific radioactivities by conjugation to a ${ }^{125}$ I-containing acylating agent. Biochem J 133: 529-539

7. Kurtz AB, Matthews JA, Nabarro JDN (1978) Insulin binding antibody: reaction differences with bovine and porcine insulin. Diabetologia 15: 19-22

8. Linde S, Hansen B (1980) Monoiodoinsulin specifically substituted in Tyr A14 and Tyr A19. Int J Peptide Protein Res 15: 495-502

9. Shore PN, Shelley WB, Kyle GC (1975) Chronic urticaria from isophane insulin therapy. Arch Dermatol 111:94-97

10. Sanchez MB, Paolillo M, Chacon RS, Camejo M (1982) Protamine as a cause of generalised allergic reactions to NPH insulin. Lancet 1: 1243

11. Green I, Paul WE, Benacerraf B (1966) The behaviour of haptenpoly-L-lysine conjugates as complete antigens in genetic responder and as haptens in non-responder guinea pigs. J Exp Med 123: $859-879$

12. Keck K (1981) Insulin as a tool for the study of immunological problems. In: Keck K, Erb P (eds) Basic and clinical aspects of immunity to insulin, de Gruyter, Berlin, pp 3-15

13. Irvine WJ, DiMario U, Feek CM, Ting A, Morris PJ, Gray RS, Duncan LJP (1978) Insulin antibodies in relation to islet cell antibodies and HLA antigens in insulin-dependent (type 1) diabetes. J Clin Lab Immunol 1: 111-114

Received: 31 December 1982

and in revised form: 25 May 1983

Dr. A. B. Kurtz

The Middlesex Hospital

Mortimer Street

London W1N 8AA, UK 